\title{
Sushruta on Human Dissection as Pre-requisite to Surgery
}

\author{
Sushruta sobre la Disección Humana como Requisito Previo a la Cirugía
}

\begin{abstract}
Arthur Saniotis ${ }^{1,2}$
SANIOTIS, A. Sushruta on human dissection as pre-requisite to surgery. Int. J. Morphol., 39(6):1787-1790, 2021.

SUMMARY: In the western surgical tradition there has been little acknowledgement of the ancient Vedic surgeon Sushruta who initiated many aspects of surgical practice. In his compendium the Sushruta Samhita, Sushruta systematised medicine in various areas. His meticulous knowledge in many branches of medicine is evident. A brilliant surgeon, he developed plastic surgical techniques, types of bandaging, hygiene practices and over one hundred surgical instruments. In this article, I focus on Sushruta's ideas on human dissection as a pre-requisite for surgery, his method of preparation of human cadavers and his anatomical pedagogy. Sushruta pioneered the instruction of cadaveric based anatomical learning which is still being used in medical teaching.
\end{abstract}

KEY WORDS: Sushruta Samhita; Cadaveric preparation; Classification; Surgical method.

\section{INTRODUCTION}

Considerable historical attention on human dissection and surgery has focussed on the Greco-Roman tradition. Alcmaeon (A $\lambda \chi \mu \alpha \iota \omega v)$ of Croton (ca. 6th-5th century BCE) made anatomical observations of the optic nerve, the tympanic-pharyngeal (eustachian) tubes, and cranial nerves (Gross, 1999). Knowledge of these structures would have necessitated dissection. However, some scholars have disputed whether Alcmaeon performed human dissection.

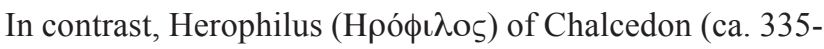
$280 \mathrm{BCE}$ ) performed both human dissection and vivisection in the Alexandrian school. The latter would have been performed on criminals convicted to death. Herophilus revised Alcmaeon's description of ocular structures, differentiated between motor and sensory nerves of the cerebrum, and examined the meninges and vascular structures of the cerebral vascular system (Pearce, 2013; Laios et al., 2017).

The gladiatorial physician Claudius Galenus ('Kla?dioV Galhn?V'), known as Galen (130 AD-200 AD), also employed dissection of humans and animals. However, since the spiritual beliefs of the times prohibited the use of human cadaver dissection Galen relied on dissecting ungulates (i.e.pigs) dogs and primates (Sinha, 2015).
However, historical evidence supports the idea that an Indian physician called Sushruta (a contemporary of Alcmaeon of Cos) regularly performed human dissection. Sushruta originated from Kashi in North India, somewhere between the 8th-6th BCE.Tradition claims that he was taught medicine by the Ayurvedic sage Dhanwantari (Deepa \& Pushpalatha, 2014). Fortunately, Sushruta's medical ideas have been catalogued in his monumental treatise, Sushruta Samhita. This book has been a key source of Indian medical lore for over two thousand years, and has been translated in the English language. Citations in this article refer to early 20th century printed editions. The Sushruta Samhita was probably the first book to systematise medicine in various areas. Scholars note that the book contained 184 chapters, describing 1120 human illnesses and a pharmacopeia of 700 hundred medicinal plants. Dozens of mineral and animal based preparations are also described (Dwivedi \& Dwivedi, 2007). Sushruta's medical curriculum was comprehensive and included gross and clinical anatomy, internal medicine, diagnostics, palpation and pulsing, surgery (i.e. thoracic surgery, orthopaedic surgery, ophthalmic surgery and plastic surgery), anaesthesia, post-operative care, nosology, herbal medicine, toxicology, embryology, paediatrics, geriatrics obstetrics, maternal care, and ethics (Dubhashi \& Avnish,

\footnotetext{
${ }^{1}$ Department of Anthropology, Ludwik Hirszfeld Institute of Immunology and Experimental Therapy, Polish Academy ofSciences, Rudolfa Weigla St. 12, 53-114 Wroclaw, Poland.

${ }^{2}$ Department of Pharmacy, Knowledge University, Erbil, Kurdistan Region. Iraq.
} 
2016). Completion of his medical curriculum took six years which is on par with current medical curricula.

A distinguishing feature of Sushruta was his systematic approach to human dissection. Firstly, Sushruta emphasised that cadavers were indispensible in acquiring extensive knowledge of human anatomy (Sushruta Samhita, 1911). Without a sound basis in cadaveric based anatomy, 1907; Dooley, 1973; Deepa \& Pushpalatha; Madhukar et al., 2017). Human cadavers served a dual purpose; dissection (shariravichaya), and exploration (sharirashodana) (Hiremath, 2016). According to Sushruta no amount of reading could substitute human dissection. As he notes: "theory without practice is like a one-winged bird that is incapable of flight" (Sushruta Samhita, 1907).

Second, Sushruta developed a method for treating human cadavers. Preparation required the removal of excreta from the intestines. The body was then was wrapped in 2 types of grass: munja (Saccharum munja) and kusha (Demostachya bipinnata), as well as hemp (Sushruta Samhita, 1911; Guleria \& Choudhary, 2015).The use of these specified plants was based on their antibacterial, antiseptic and anti-inflammatory properties which assisted in preservation of the cadaver (Sharma, 2013). The body was then placed in a cage before it was submerged in water for approximately seven days to allow proper decomposition. It was essential that the cadaver was exposed to flowing water in order to reduce the rate of decomposition and remove micro-organisms from the body's surface (Sushruta Samhita, 1911). After the required period (approximately seven days) the body was then taken out of water, removed from its cage and carefully scoured with a bamboo strip of Kusa blade or grass roots (Sushruta Samhita, 1911; Singh \& Vyas, 2011; Guleria \& Choudhary).

The scrubbing removed the superficial skin layers, thereby accessing musculoskeletal and visceral tissue
(Hiremath). Sushruta's methodological approach towards cadaveric preparation were informed by the medical traditions of his time (Raveenthiran, 2011).

Sushruta had created a checklist in order to ensure that the right cadaver was processed. This was based on the following criteria (Sushruta Samhita, 1911):

1. Death had not been due to protracted disease or poisoning. 2. The body had to have been intact.

3. The body did not belong to an elderly individual (adeerghavyadhipeedita).

On a comparative note, modern body donation programs at medical schools also abide by a similar checklist for acceptance. For example, bodies are rejected for embalming at Australian medical schools if they have been mutilated or if the individual had acquired immune deficiency syndrome (AIDS) or hepatitis C. Not only was Sushruta's selection criteria the first of its kind but also set the standard for future cadaveric programs in western medicine.

For Sushruta, anatomical dissection was fundamentally geared towards surgery (shalya karma), which he considered as being a superior form of medical treatment (Sushruta Samhita, 1907). Without a comprehensive study of anatomy, surgery was impossible (Crawford, 2003). Anatomy was a practical pursuit in order to observe and understand morphological structures to a high degree of accuracy (Sushruta Samhita, 1911).

In this context, cadavers provided an indispensable storehouse of knowledge. According to the Sushruta Samhita, the body is divided into six major divisions: head (shira), trunk (madhya), and upper and lower limbs (shakya). Additionally, each of these 6 parts is further sub-divided into smaller divisions, providing detailed morphological description of human structure and function. Sushruta's comprehensive

Table I. Anatomical structures classified by Sushruta; modified from Srikantha Murthy (2012).

\begin{tabular}{|c|c|}
\hline Body tissue (dhatu) & $\begin{array}{l}7 \text { types: nutrient material (rasa), blood (rakta), bones (asthi), muscle (mams), bone marrow } \\
\text { (majja), fatty tissue (meda), semen (shukra). }\end{array}$ \\
\hline External openings (srotas) & 9 types in males; 12 types in females: 3 extra are vagina and breast openings. \\
\hline Osteology & $\begin{array}{l}300 \text { bones (asthi) of various types: } 900 \text { ligaments (snayu) which are further classified into } 4 \\
\text { types. } 16 \text { tendons (kandara); } 4 \text { each in the neck, back, foot and upper extremities. }\end{array}$ \\
\hline Joints (sandhi) & $\begin{array}{l}2 \text { types, fixed (achala sandhi) and moving (chala sandhi). } \\
\text { Moving joints were further categorised into } 8 \text { types. }\end{array}$ \\
\hline Muscles (pesi) & $\begin{array}{l}500 \text { different muscles, } 400 \text { of which were in the extremities, } 66 \text { in the trunk and } 34 \text { in the neck } \\
\text { area. }\end{array}$ \\
\hline Muscular fascia (mamsarajju) & 4 types of muscular fascia. \\
\hline Vascular structures & 24 arteries (dhamani). 700 veins $($ sira $)$ \\
\hline Internal organs (ashaya) & $\begin{array}{l}\text { Males have } 7 \text { organs: lungs (shleshmashaya), stomach (amashaya), liver and spleen } \\
\text { (raktashaya), gall bladder (pittashaya), intestine (pakwashaya), large intestines (vatashaya), } \\
\text { urinary bladder (mutrashaya). Females have } 8 \text { organs: extra one being uterus (garbhashaya). }\end{array}$ \\
\hline
\end{tabular}


anatomical classification is central to anatomical and surgical instruction in the 21 st century. Moreover, from his dissections Sushruta was able to classify thousands of structures and tissue types, which is beyond the scope of this article. Some of his findings are found in the Sushruta Samhita (Table I).

During dissection Sushruta stressed the importance of observation, a fundamental skill of surgery. In order to improve the surgical skills of his students Sushruta devised various modules to increase proficiency in 8 surgical competencies: cutting, incision (chedya), excision (bhedya), suturing (sivya), fluid drainage (visravaniya), solid tissue extraction(ahrya), puncturing (vedhya), scarifying (lekhya), and probing (eshya) (Sushruta Samhita, 1907; Kansupada \& Sassani, 1997; Srikantha Murthy, 2012).These included using the veins of dead animals, and hollow lotus stalks for practice in puncturing gourds, jackfruit and other vegetables, and teeth of dead animals for extraction, excision and incision; stretched hairy animal hides for scraping; using skin or hides for suturing; meat for cauterising (Sushruta Samhita, 1907; Kansupada \& Sassani). Additionally, cutting strokes on a vertical axis were emphasised (Wujastyk, 2003). Lateral incisions were to be performed on the head, eyebrows, cheek, temple, lower lips, abdomen, loins and groin. This last point is especially interesting since incising along a vertical axis is advocated in various kinds of surgery (i.e. abdominal and thoracic surgery) in order to evade nervous and vascular structures and to improve post-operative wound healing. In contrast, incisions to the anus and penis hand were to be performed in a semi-circular fashion while incisions to the hand were to resemble the moon disc (Sushruta Samhita, 1907).

Sushruta's contributions to surgery are immense and have been noted by various theorists. He excelled in different kinds of surgery including orthopaedic surgery, ophthalmic surgery, and plastic surgery. In relation to the latter, he was the first known recorded person to perform plastic surgery to the ears, nose (rhinoplasty) and lips.This was performed by the transplantation of skin grafts and skin flaps. Plastic surgery to the ear (ganda-karna) consisted of removing a piece of flesh from the cheek and adhering it to the amputed ear (Sushruta Samhita, 1911; Kansupada \& Sassani). Sushruta mentions 10 different kinds of adhering surgical methods to the ears, depending on the location and extent of the ear lesion. For example, the adhesion method known as áháryaya consisted in the bilateral reconstruction of the earlobes using skin tissue procured from both cheeks (Sushruta Samhita, 1911). Sushruta's understanding of grafting and blood flow are still practiced by current cosmetic surgeons. He performed surgery for cataracts and trachoma, laparotomies for the removal of foetuses and created over 100 surgical instruments, dividing them into 6 major groups (Sushruta Samhita, 1907). Many of his surgical instruments were inspired from the shapes of animals such as birds (Sushruta Samhita, 1907). He also encouraged surgeons to create new kinds of surgical instruments where necessary. Sushruta explained the meticulous production of surgical instruments (Sushruta Samhita, 1907). Moreover, he developed 14 types of bandages, specified hygienic practices for public health and surgery and pioneered the use of anaesthesia (cannabis and wine were used) (Sushruta Samhita, 1907; Sushruta Samhita, 1911; Bhattacharya, 2009; Dubhashi \& Avnish). He instigated strict surgical procedures which form the basis of current surgical practice (Singh et al., 1970). Sushruta's surgical method was based on 3 parts: pre-surgical procedure (purva-karma), surgical procedure (pradhana-karma), and post-surgical procedure (pashchat-karma) (Fig. 1).

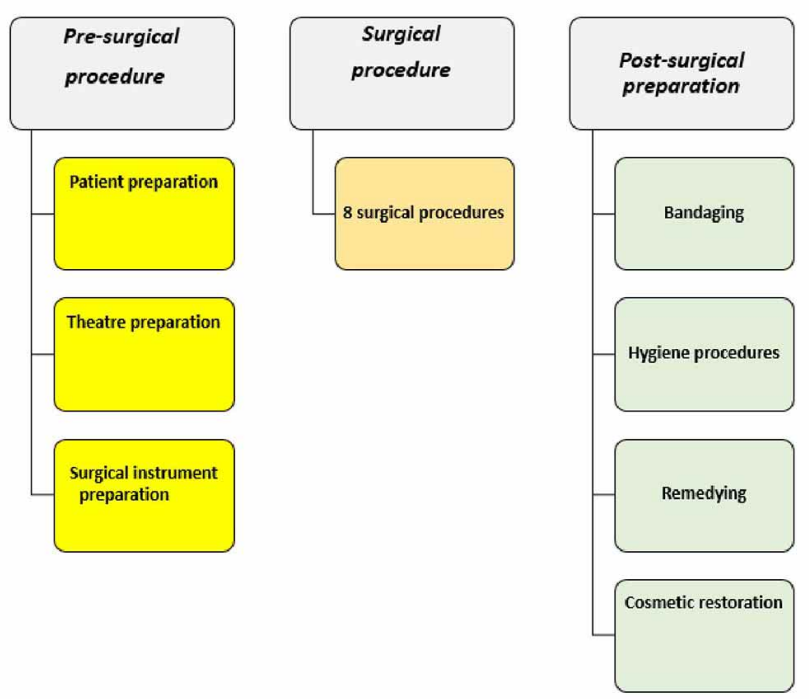

Fig. 1. Sushruta's tripartite surgical method. Modified from Singh, et al. (1970).

Sushruta's achievements in anatomy, human dissection and surgery mark his genius and provide a lasting legacy to medicine and surgery. His insistence on the use of human dissection as a principal method in surgical practice would be latter confirmed by the Greco Romans, Arabs, and Europeans in the medieval and Renaissance periods.

SANIOTIS, A. Sushruta sobre la disección humana como requisito previo a la cirugía. Int. J. Morphol., 39(6):1787-1790, 2021.

RESUMEN: En la tradición quirúrgica occidental existe escaso reconocimiento del antiguo cirujano védico Sushruta, quien inició muchos aspectos de la práctica quirúrgica. En su compendio, el Sushruta Samhita, Sushruta sistematizó la medicina en varias áreas. Es evidente su meticuloso conocimiento en muchas ramas de la medicina. Cirujano brillante, desarrolló técnicas de ciru- 
gía plástica, tipos de vendajes, prácticas de higiene y más de cien instrumentos quirúrgicos. El enfoque de este artículo se centra en las ideas de Sushruta sobre la disección humana como requisito previo para la cirugía, su método de preparación de cadáveres humanos y su pedagogía anatómica. Sushruta fue pionero en la instrucción del aprendizaje anatómico basado en cadáveres que todavía se utiliza en la enseñanza médica.

PALABRAS CLAVE: Sushruta Samhita; Preparación de cadáveres; Clasificación; Método quirúrgico.

\section{REFERENCES}

Bhattacharya, S. Sushrutha - our proud heritage. Indian J. Plast. Surg., 42(2):223-5, 2009.

Crawford, C. S. Hindu Bio Ethics for the Twenty First Century. Albany, State University of New York Press, 2003.

Deepa, B. \& Pushpalatha, K. Contributions of Sushruta to anatomy. Anat. J. Afr., 3(2):362-5, 2014.

Dooley, D. A dissection of anatomy. Ann. R. Coll. Surg. Engl., 53(1):1326, 1973.

Dubhashi, S. P. \& Avnish, A. Sushruta: Foundation for surgical practice. J. Krishna Inst., Med. Sci. Univ., 5:145-50, 2016.

Dwivedi, G. \& Dwivedi, S. Sushruta - The clinician-teacher par excellence. Indian J. Chest Dis. Allied Sci., 49:243-4, 2007.

Gross, C. G. A hole in the head. Neuroscientist, 5(4):263-8, 1999.

Guleria, M. \& Choudhary, K. R. A glimpse of the contributions of Acharya Sushruta in surgery. World J. Pharm. Pharm. Sci., 9:291-317, 2015.

Hiremath, K. B. Ancient ayurvedic method of preservation of dead body and dissection. Int. Ayurvedic Med. J., 1:86-90, 2016.

Kansupada, K. B. \& Sassani, J. W. Sushruta: The father of Indian surgery and ophthalmology. Doc. Ophthalmol., 93:159-67, 1997.

Laios, K.; Moschos, M. M. \& Androutsos, G. Herophilus of Chalcedon (ca. 330-250 BC) and ocular anatomy. A review. Ital. J. Anat. Embryol., 122:151-4, 2017.

Madhukar, L. S.; Bhatnagar, V.; Nivrutti, B. A. \& Bhatnagar, S. A critical review study on dissection techniques in ancient Indian anatomy in context to its clinical significance. World J. Pharm. Med. Res., 3:371$5,2017$.

Pearce, J. M. The neuroanatomy of Herophilus. Eur. Neurol., 69:292-5, 2013.

Raveenthiran, V. Knowledge of ancient Hindu surgeons on Hirschsprung disease: evidence from Sushruta Samhita of circa 1200-1600 B.C. J. Pediatr. Surg., 46:2204-8, 2011.

Sharma, P. V. Dravyaguna-vijnana. Vol. II (Vegetable drugs). Varanasi, Chaukhambha Bharati Academy, 2013.

Singh, L. M.; Thakal, K. K. \& Deshpande, P. J. Sushruta's contributions to the fundamentals of surgery. Indian J. Hist. Sci., 5:36-50, 1970.

Singh, R. K. \& Vyas, M. K. Surgical procedures in Sushruta Samhita. Int. J. Res. Ayurveda Pharm., 2:1444-1450, 2011.

Sinha, D. N. Ancient human cadaveric dissection. Natl. J. Clin. Anat., 4:537, 2015.

Srikantha Murthy, K. R. Sushruta Samhita (English Translation). Vol. I (Sharirasthana: chapter V). Varanasi, Chaukhamba Orientalia, 2012.

Sushruta Samhita (Vol. I). Bhishagratna K.K.L. (Translator). Calcutta, J. N. Bose, 1907.

Sushruta Samhita (Vol. II). Bhishagratna K.K.L. (Translator). Calcutta, Bharat Mihir Press, 1911.

Wujastyk, D. The Roots of Ayurveda, Selections From Sanskrit Medical Writings. London, Penguin Books, 2003.
Corresponding author:

Arthur Saniotis

Department of Anthropology

Ludwik Hirszfeld Institute of Immunology and Experimental

Therapy

Polish Academy of Sciences

Rudolfa Weigla St. 12, 53-114

Wroclaw

POLAND

Email:arthur.saniotis@hirszfeld.pl

Received: 15-06-2021

Accepted: 12-07-2021 